\title{
In-Service Training Opportunities Provided for Business Educators for Improving Job Performance in Secondary Schools in Delta State
}

\author{
Godwin Onnoh Onajite PhD \\ Department of Vocational and Technical Education \\ Ekiti State University \\ Nigeria
}

\begin{abstract}
This study examined in-service training programme opportunities provided for business educators for improving their job performance in secondary schools in Delta State. Three research questions guided the study. The study employed descriptive survey research design. Population of this study consisted of 2,100 business educators within 448 public secondary schools in Anambra State. Sample size of this study constituted a total of 630 business educators selected from 448 public secondary schools using the proportionate stratified random sampling technique. A 24-item researchers' self-developed questionnaire titled "In-service Training Opportunities Questionnaire (ISTOQ)" arranged into three (3) clusters, and structured on 4 point scale which weighted as follows: (a) Strongly Agree (SA) - 4, Agree (A) - 3, Disagree (D) - 2, Strongly Disagree (SD) - 1, was used as the main instrument for data collection in this study. The research instrument was validated by three experts and reliability determined through a pilot test which yielded an internal consistency reliability value of 0.82, showing that the instrument was trustworthy in collecting the necessary information for the study. Method of data collection involved a direct and hand delivery contact with the respondents. Data collated were analyzed using the mean score and standard deviation. The findings of this study revealed others that induction training, on-the-job and off-the-job in-services training opportunities were not appropriately provided for business educators in the secondary schools in Delta State in order to guarantee or ensure their job performances. From the findings of this study, recommendations were proffered and among them were that principals should ensure that newly employed business educators/teachers always undergo appropriate induction training programmes in order to boost their job performances. This includes that induction training programmes like specific orientation, physical tour around the school premises, short seminars and the school's handbook/pamphlet which describes the general philosophy, goals and objectives of the schools should highly be encouraged in the school for increased performances. On-the-job training opportunities should be highly provided for business educators by their principals including the State Government and the Delta State Post Primary Education Board (PPEB).
\end{abstract}

Keywords: In-service, Training, Business Educators, Improving, Job Performance, Secondary Schools, Delta State

\section{Introduction}

Business educators just like their counterparts in other fields of endeavour are important machineries for effectiveness of teaching and learning in business education. Business educators implement educational policies at the classroom level. The quality of teaching and learning in business studies education in the secondary schools lies upon the competency and effectiveness of the educators. It is the educators that determine the quality of education provided for students in the secondary schools. In Nigeria, education is regarded as "an instrument per excellence for social and economic reconstruction of the nation", therefore realization of Nigeria's collective aspiration of being among the top 20 developed nations of the world by the year 2020, means that citizen will continue having access to quality and standard education in the education institutions, which is possible with the contributions of great educators or teachers (Federal Republic of Nigeria, FRN, 2013). The contributions of great and quality educators in the education system cannot be overemphasized. Without the proficiency, competency and efficiency of the educators, especially in business education, the entire education system would be flooded with poor quality school graduates, who cannot make solid contributions to national development. Thus, the need for educators' of business education continuous development, which can be made possible through in-service training and retraining opportunities provided for them. 
Looking at the importance of studying business education in the secondary schools, this subject has significant impact on national development. According to Onajite and Oyerinde (2015), business education encompasses education for business, office occupation, economic understanding and entrepreneurship. It seeks to develop in the learners basic skills for personal use in the future, enabling them acquire the basic knowledge and skills of business education in order to relate these knowledge and skills acquired to national development. Business education further develops in the learners, basic skills in office occupation and prepares them for further training in the subject area (Onajite \& Oyerinde, 2015). In the secondary schools in Delta State, business education is studied under the following subjects as: business studies for junior secondary classes, and accounting, marketing, commerce and economics for senior secondary classes. With the study of business education, secondary school students can play important role in socio-economic development of the society. Students' will be able to defend themselves in the business world and world of work. Therefore, it is important to support business education students at the secondary school level with competent educators or teachers who are capable of bringing out the best potentials in every student for the society's development. In addition, the Federal Republic of Nigeria (FRN, 2013) pointing out the importance of educators (that is: teachers) in the education system highlighted that teachers play pivotal role in provision of quality education at all levels of education. And need be for the production of highly motivated, sound, conscientious and efficient classroom teachers at all levels of education. In recognition of the roles of teachers and their need for continuous training and retraining, the FRN (2013:43) further stressed that:

"All teachers in educational institutions shall be professionally trained through various university, polytechnic and teacher education training programmes. All newly recruited teachers shall undergo a formal process of induction. In-service training shall be an integral part of continuing teacher education. It is mandatory that all school proprietors provide in-service education for teachers. Promotion opportunities shall continue to be created for unhindered professional growth at all levels. All teachers in educational institutions shall be required to undergo training in methods and techniques of teaching and various educational institutions shall pursue their goal through staff development....."

This above FRN statements shows that in-service training and retraining which is vital for every educator in the secondary school is a necessity. In-service training on the other hand entails training organized for teachers who are already working as teachers or qualified as teachers. Kaur (2012) describes in-service training as a planned educational experience provided in the job setting and closely identified with services in order to help person perform more effectively as a person and as a worker. This training can take many forms as induction training, on-the-job training and off-the-job training. Udeozor (2004) defines staff in-service training as efforts made by any institution to boost competences of their employees and where the required teachers are not available, efforts have been made for training and retraining of workers. The importance of in-service training programmes is that they ensure that educators acquire the basic skills and competences that will enable maintain minimum standards and quality assurance of instructional activities in school (FRN, 2013). According to Ezugoh (2017) in-service training provides teachers information on professional opportunities for self-improvement and development to meet the challenges and requirements of new equipment and new techniques of performing a task. In-service training and development programmes can acquaint business educators with research on the instructional process and new methods of teaching in business education.

McDiarmid and Bright cited in Manduku, Edward and Cheruiyot (2017) asserted that business educators need to know, be able to do and care about knowledge including the subject matter, pedagogical content knowledge, curriculum, pedagogy, educational foundations, policy context, diverse learners and their cultures, technology, group processes and dynamics, theories of learning, motivation and assessment, among others. The scholar further noted that business educators should be able to craft skills in teaching business education including planning, organizing and orchestrating business education instruction, using instructional materials and technology, disciplinary learners, managing groups, monitoring and evaluating learning, collaborating with colleagues and other agencies and showcase their dispositions including beliefs, attitudes, values and commitment while executing their job for utmost performances. Zamumuzi (2004) opined that in-service programmes help business educators to keep abreast of developments in their respective business education subjects, as well as in the development of education in general. However, there are different types of in-service training opportunities that could be offered to business educators in the secondary schools and they include induction training, on-the-job and off-the-job training programmes. 
Kaur (2012) posited that induction training is a brief or orientation about an organization's philosophy, purpose, policies and regulations given to each worker during her or his first days of employment in order to ensure his or her identification with organization's philosophy, goals and norms. The need for induction training is for increased retention of newly hire employees, improved employee morale and increased productivity. For Ezugoh (2017), induction training can also include an introduction to the company ethos, values and culture so that the employee is aware of the behaviours expected of them. Ezugoh further saw on-the-job training as training provided during the regular performance of duties. This can take varieties of forms as: job rotation, guidance, shadowing, observations, coaching and mentoring. Off-the-job training on the other hand is provided for educators as lectures and tutorials. This training is usually provided away from the employee's usual work environment. Off the job training may be in the same building or off site. This training may be provided by trainers working for the same employer as the employees being trained or an outside company hired by the employer. Off the job training is often used to support the employees studying for a formal qualification, certification or exam. Examples of this type of training includes workshops, seminars, conferences, short and long courses, university education, distance learning or self study, among others.

Given all the benefits of in-service training programmes, their main purpose is to improve workers job performances. Job performance refers to as the disposition of teachers towards their work which involves a collection of numerous attitudes to work. It also refers to workers behavioural aspect which has to do with what people do while at work, the action itself. Job performance covers the fulfillment of the requirements that are part of the contract between the employer and employee. Educators when properly and constantly trained and retrained, their performance automatically reaches towards high level (Munir \& Khatoon, 2015). The indices of business educators' job performance therefore as identified by Valdez (2006) and Agu (2014) can be showcased through their attitude to work, efficiency in the teaching task, proficiency/competency during presentations in the classroom, commitment to duty, quality of work and productivity, and students' academic performance and achievements, among others. Effective teaching essentially requires well-trained and competent teachers that are generally expected to contribute to the improvement of the society and to participate in its activities through their effective teaching and job performances. Several studies have been conducted on staff in-service training programmes, some indicated the effectiveness of in-service training programmes and others have presented a mix. Manduku, Edward and Cheruiyot (2017) study on the effectiveness of in-service teacher training programmes in Kenya found that these programmes were effective on improvement on teachers' development of student-teacher relationship, use of teaching-learning resources, and on students' evaluation.

Krueger and Rouse in a study cited in (Ezugoh, 2017) found that employees that attended in-service training, became more invested, committed and better working employees. These employees were shown to seek more job upgrades, receive more performance awards, and have better job attendance than those that did not attend training. But Ezugoh's study had a mix and found that in-service training programmes such as induction and orientation training, on-the-job training like mentoring, professional courses in adult education, free educational scholarship, long and short training courses abroad and computer-based training were not appropriately provided for educators for in order to improve their performances for facilitating learning in literacy centres. Walsh and Taylor (2007), study has shown that in-service professional training activities are correlated with productivity and retention.

The use of formal training programmes is associated with significantly higher productivity growth. Samupwa (2008) examined the effects of teacher training on the administrative work and teacher's behaviour in the classroom. Result showed significant changes in behaviour of the teachers in classroom and on the administrative work. Seyed, Hashemi and Ali (2014) conducted a study and investigated ways of improving the effectiveness of the mechanisms in-service courses for Lamerd teacher's job performance in the fundamental transformation plan in the 2013-2014 years. The results showed that the growth and performance of in-service courses for teachers was effective, this owing to the continuous training they had. Another study of Ofojebe and Chukwuma (2015) on utilization of continuous professional development - CPD for academic staff effectiveness in the higher education sector in contemporary Nigeria revealed the need for constant in-service and on-the-job training programmes to be organized for staff for their effectiveness and efficiency.

From all these studies shows that effectiveness of in-service training programmes on teachers' job performance. Researcher's observation of about business educators in Delta State secondary school showcases that many teachers are inexperienced in their job. Most of their tasks in teaching and learning in business education also showcase poor performances. 
They lack the requisite skills and competences that will motivate students and boost their performances in business education. This has been indicated in students' low interest in studying business education subjects especially at the senior secondary level, likewise in students' poor academic performances in both internal and external examinations in business education. This situation existing in Delta State which points to the direction of the need for in-service training programmes for business educators has motivated the researcher to conduct the present study in order to find out in-service training programme opportunities provided for business educators for improving their job performance in secondary schools in Delta State.

\section{Statement of the Problem}

Business educators are pivotal in development of effective teaching and learning in business education, thus, opportunities created for them to actively participate in in-service training and retraining programmes will enable them to constantly acquire new skills, competences and concepts in business education, new models for overcoming emerging challenges of imparting knowledge to the present generation and to meet the emerging dynamics in technological, practical and theoretical learning as it affects and relates to business education. Notably, a glance at the secondary schools in Delta State seems as if there is a problem in the way and manner business educators perform their functions for achievement of the goals and objectives of business education. A lot of these educators recently showcase inefficiency in their job performance and this has negative consequences on achieving positive results in the teaching and learning of business education in the secondary schools. The inability of business educators to execute their functions effectively reflects upon the type of in-service training opportunities provided for them. Their lack of in-service training programmes which showcases their poor performances can be observable in such scenario like educators poor attitude and commitment to work, students' withdrawal from studying business education subjects at the junior classes, students' poor performances in examinations and most secondary schools in Delta State have gone to the extent of even putting a halt on students' studying business studies at the junior classes, among others. All these matters relates to in-service training programmes offered for business educators. Whereby training opportunities are created for business educators, this will improve their job performances and positively impact on students' academic performances and achievements. The ugly situation in Delta State as regards to business educators' lack of in-service training programmes has created a gap which needs to be filled for quality teaching and learning to triumph in business education. The need to find out in-service training programme opportunities provided for business educators for improving their job performance in secondary schools in Delta State, has then become the problem of this study.

\section{Purpose of the Study}

The aim of this study was to examine in-service training opportunities provided for business educators for improving their job performance in secondary schools in Delta State. Specifically, the study aimed at ascertaining:

1. Induction training opportunities provided for business educators for improving their job performance in secondary schools in Delta State.

2. On-the-job training opportunities provided for business educators for improving their job performance in secondary schools in Delta State.

3. Off-the-job training opportunities provided for business educators for improving their job performance in secondary schools in Delta State.

\section{Research Questions}

1. What are the induction training opportunities provided for business educators for improving their job performance in secondary schools in Delta State?

2. What are the on-the-job training opportunities provided for business educators for improving their job performance in secondary schools in Delta State?

3. What are the off-the-job training opportunities provided for business educators for improving their job performance in secondary schools in Delta State?

\section{Methodology}

The study employed a descriptive survey research design. The essence of employing this research design was to enable the researcher conduct a field investigation by sampling small portion out of a large population of business educators in order to determine in-service training opportunities provided for business educators for improving their job performance in secondary schools in Delta State. 
The population of the study consisted of 2,100 business educators within 448 public secondary schools in Delta State of Nigeria. This population comprised teachers teaching various business education subjects at the junior and senior secondary school classes in Delta State which includes 665 business studies educators, 254 accounting educators, 588 commerce educators and 593 economics educators making a total of 2,100 business educators (Source: IT Unit in Planning, Research and Statistics Department, Delta State Post Primary Education Board PPEB, January, 2018).

A total of 630 business educators selected using the proportionate stratified random sampling technique was sampled in the study. To do this selection, the business educators were stratified according to their teaching subjects based on Business Studies, Accounting, Commerce and Economics in the 448 public secondary schools in Delta State. The samples were randomly drawn from each subject areas at $30 \%$. Justification for this selection was to enable the researcher select and control a sizeable number of participants from the large population size of business educators understudied in the study. Nworgu (2015) opined that $10 \%$ to $80 \%$ of any given population is adequate for a research work.

A 24-item researcher-developed questionnaire titled "In-service Training Opportunities Questionnaire (ISTOQ)" arranged into three (3) clusters, and structured on 4 point scale which weighted as follows: (a) Strongly Agree (SA) - 4, Agree (A) - 3, Disagree (D) - 2, Strongly Disagree (SD) - 1, was used as the main instrument for data collection. Although, construction of this research instrument was guided mostly by the purpose of the study and research questions, some items in this instrument were adapted from Ezugoh (2017) study which also investigated the in-service training opportunities provided for facilitators for facilitating learning in the adult literacy in Delta State. The instrument was titled: "Motivational Strategies Provided for Educators' for Facilitating Learning in Adult Literacy Centres Questionnaire - (MSPELALCQ)". The portion/part of Ezugoh's instrument on in-service training provided for educators was adapted because it related to the present study, although few changes were made in order to suit the present study.

The research instrument was validated by three experts. Two of these experts were consulted from Business Education Department and one expert from Educational Foundations Department (Measurement and Evaluation expert), Faculty of Education, Nnamdi Azikiwe University, Awka. The experts determined the face and content validity of the instrument in relation to the sentence construction, double-barrel items and content coverage. Corrections made by the experts on the instrument were incorporated before the final distribution of the research instrument. Reliability determined through a pilot test. The pilot test was conducted by sampling 30 business educators from 6 public secondary schools in Anambra State. Anambra State which is not part of the study shares common boundary with Delta State. The pilot test was conducted in Anambra State in order to avoid bias, that is, a situation whereby the actual respondents in Delta State will not to have an initial knowledge of the instrument before it was finally administered on them. Scores obtained after the pilot test was measured using Cronbach Alpha statistics which yielded an internal consistency reliability value of 0.82 , showing that the instrument was reliable and trustworthy in terms of collecting the necessary data for the study.

Method of data collection involved a direct and hand delivery contact with the respondents. Four research assistants were employed in order to administer the research instrument to the respondents. These research assistants were individuals familiar with the terrain and public secondary schools selected for sampling. They received briefings and instructions on how to communicate to the respondents concerning the purpose of the study and collect the necessary information with the questionnaire. A total of 630 copies of the questionnaire were distributed to the respondents and all of them were retrieved. Data collated were analyzed using mean score and standard deviation. The mean score was benchmarked at 2.50. Any mean score that rated at and above 2.50 was considered as agreement with the statement and therefore, accepted, while, any mean score which rated at 2.49 and below 2.50 was considered as disagreement with the statement and therefore, rejected. 


\section{Presentation of Results}

Table 1: Mean Scores and SD on Induction Training Opportunities Provided for Improving Job Performance in Secondary Schools in Delta State $(\mathrm{N}=630)$

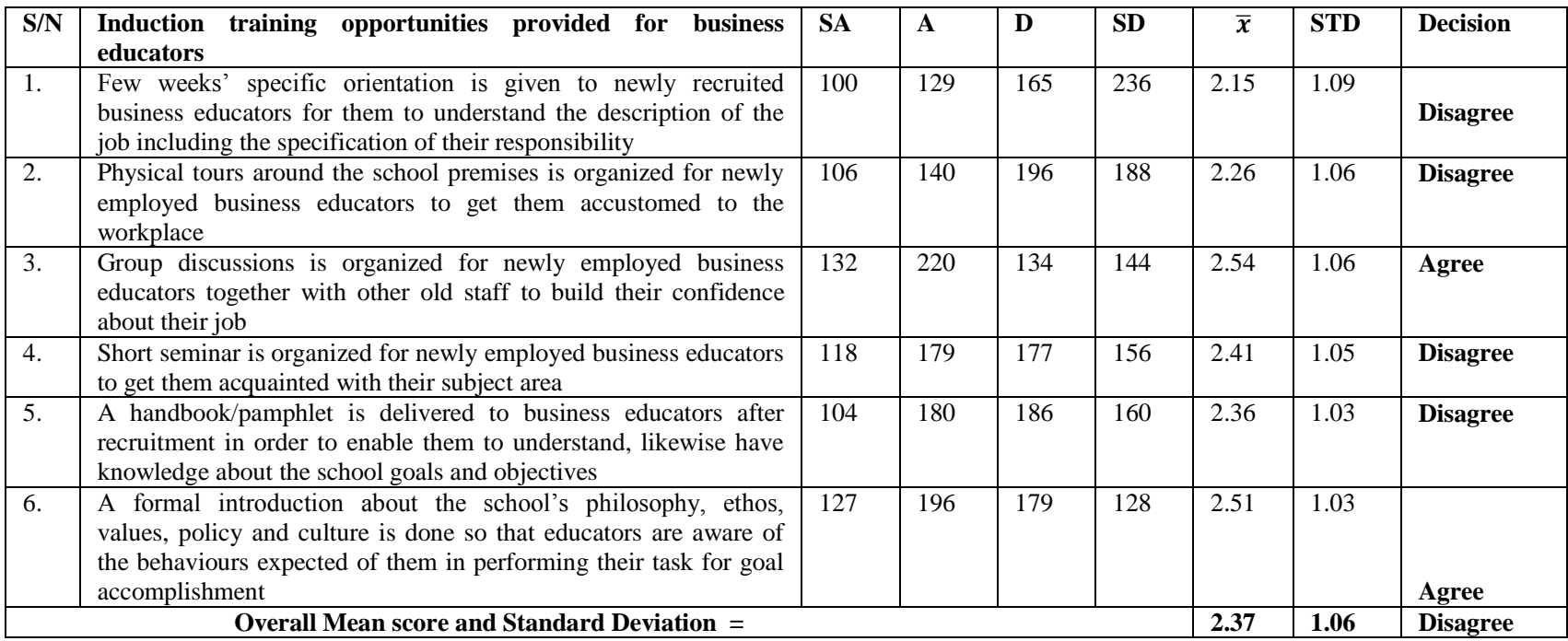

Analysis of the result represented in Table 1 showed only items 3 and 4 rated above the acceptable mean score of 2.50 in agreement to these statements. This analysis indicated that these were the only two areas where induction training opportunities were appropriately provided for the business educators. All other items 1, 2, 4 and 5, rated below the acceptable mean score of 2.50 in disagreement to these statements. By this analysis, appropriate induction training opportunities were not appropriately provided for the business educators in these areas. The overall mean score of 2.37 was even below the mean benchmark of 2.50 which indicated that the respondents reacted negatively to many of the statements in the table. The standard deviation which ranged between 103 and 1 . 09 showed that there was a close variation in the mean scores. The scores were not too far from each other. However, the result indicated that induction in-services training opportunities provided for business educators were not appropriately provided for them for their job performance in the secondary schools in Delta State.

Table 2: Mean Scores and SD on On-the-Job Training Opportunities Provided for Improving Job Performance in Secondary Schools in Delta State $(\mathrm{N}=630)$

\begin{tabular}{|c|l|l|l|l|l|l|l|l|}
\hline S/N & On-the-job training opportunities provided for business educators & SA & A & D & SD & $\overline{\boldsymbol{x}}$ & STD & Decision \\
\hline 7. & $\begin{array}{l}\text { The inexperienced business educators are allowed to be constantly } \\
\text { coached by the older ones in order to lessen their chances of making } \\
\text { mistakes on the job }\end{array}$ & 139 & 123 & 212 & 156 & 2.39 & 1.08 & Disagree \\
\hline 8. & $\begin{array}{l}\text { Mentoring through observation of experts is used as means of } \\
\text { improving business educators high performances }\end{array}$ & 125 & 121 & 207 & 177 & 2.31 & 1.08 & Disagree \\
\hline 9. & $\begin{array}{l}\text { Opportunities are created for business educators job rotation in order } \\
\text { to gain better insight of the school's organization for increased job } \\
\text { performances }\end{array}$ & 138 & 240 & 120 & 132 & 2.61 & 1.05 & Agree \\
\hline 10. & $\begin{array}{l}\text { Business educators enjoy transfer from one school to another in order } \\
\text { to uncover their capacities likewise potentials to make positive impact } \\
\text { on the job }\end{array}$ & 158 & 190 & 164 & 118 & 2.62 & 1.05 & Agree \\
\hline 11. & $\begin{array}{l}\text { Business educators consult their senior colleagues or supervisors for } \\
\text { guidance only when they face difficult task so that they are able to } \\
\text { know how to perform the task and to what standard }\end{array}$ & 200 & 138 & 152 & 2.52 & 1.08 & Agree \\
\hline 12. & $\begin{array}{l}\text { Computer-based training is always provided for business educators in } \\
\text { order to equip them with the necessary information to function } \\
\text { actively in teaching and learning process as it relates to modern } \\
\text { practices in business education }\end{array}$ & 111 & 130 & 187 & 202 & 2.24 & 1.08 & Disagree \\
\hline 13. & $\begin{array}{l}\text { Opportunities for promotional training is provided for business } \\
\text { educator during promotions }\end{array}$ & 130 & 154 & 162 & 184 & 2.37 & 1.11 & Disagree \\
\hline 14. & $\begin{array}{l}\text { Workshops and seminars are constantly organized in the school for } \\
\text { business educators to improve their competences for good } \\
\text { performances in their profession }\end{array}$ & 100 & 124 & 201 & 205 & 2.19 & 1.06 & Disagree \\
\hline
\end{tabular}


Analysis of the result represented in Table 2 showed only items 9, 10 and 11 rated above the acceptable mean score of 2.50 in agreement to these statements. This analysis indicated that these were the only three areas where on-the-job training opportunities were appropriately provided for the business educators. All other items $7,8,12$, 13 and 14, rated below the acceptable mean score of 2.50 in disagreement to these statements. By this analysis, appropriate on-the-job training opportunities were not appropriately provided for the business educators in these areas. The overall mean score of 2.40 was even below the mean benchmark of 2.50 which indicated that the respondents reacted negatively to many of the statements in the table. The standard deviation which ranged between 1.05 and 1.11 showed a close variation in the mean scores. The scores were not too far from each other. However, the result indicated that on-the-job in-services training opportunities provided for business educators were not appropriately provided for them for their job performance in the secondary schools in Delta State.

Table 3: Mean Scores and SD on Off-the-Job Training Opportunities Provided for Improving Job Performance in Secondary Schools in Delta State

$\mathrm{N}=630$

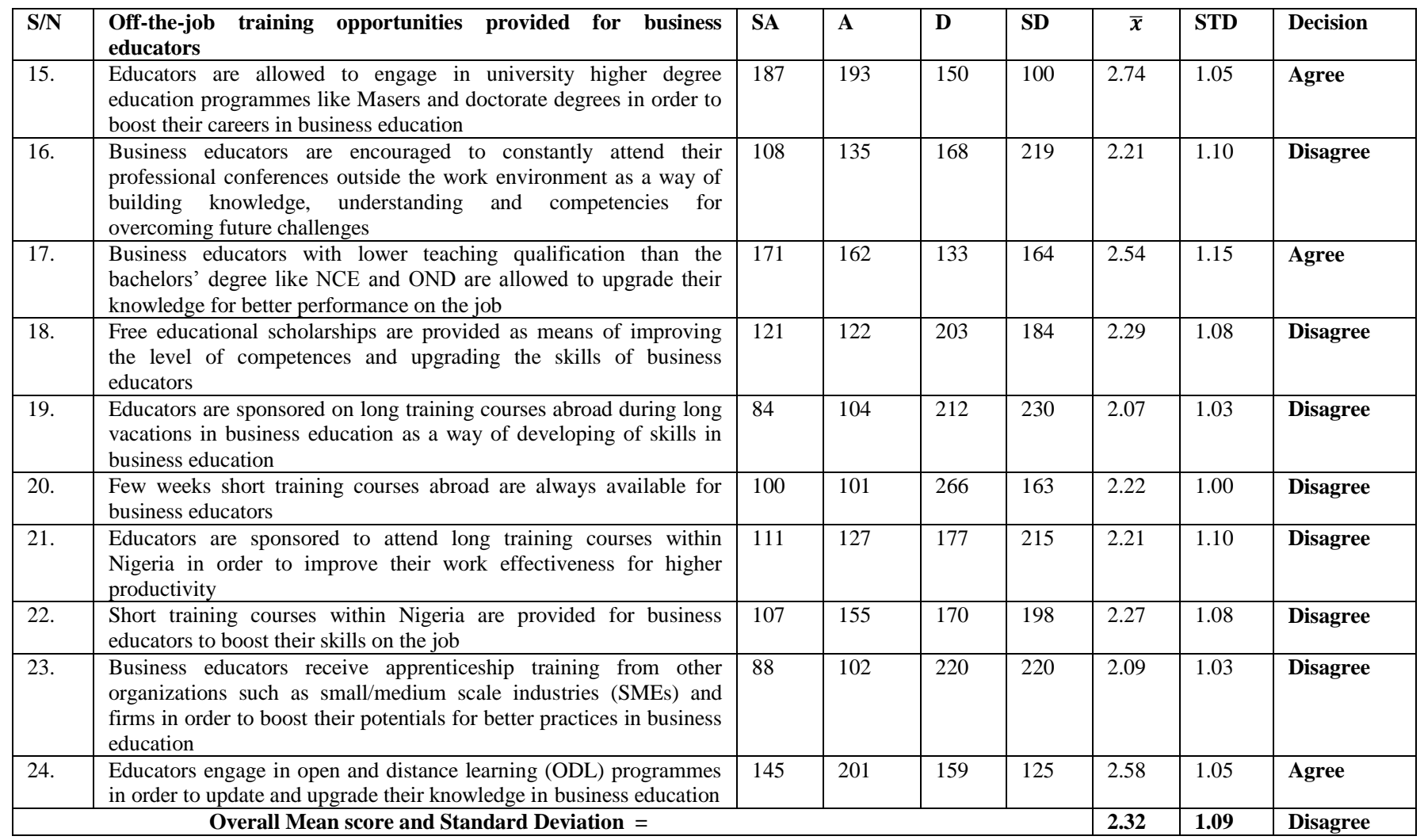

Analysis of the result represented in Table 3 showed only items 15, 17 and 24 rated above the acceptable mean score of 2.50 in agreement to these statements. This analysis indicated that these were the only three areas where off-the-job training opportunities were appropriately provided for the business educators. All other items 16, 18, $19,20,21,22$ and 23 , rated below the acceptable mean score of 2.50 in disagreement to these statements. By this analysis, appropriate off-the-job training opportunities were not appropriately provided for the business educators in these areas. The overall mean score of 2.32 was even below the mean benchmark of 2.50 which indicated that the respondents reacted negatively to many of the statements in the table. The standard deviation which ranged between 1.03 and 1.15 showed a close variation in the mean scores. The scores were not too far from each other. However, the result indicated that on-the-job in-services training opportunities provided for business educators were not appropriately provided for them for their job performance in the secondary schools in Delta State.

\section{Discussion of Findings}

The findings of this study revealed that in-service training opportunities in the various aspects of induction training, on-the-job and off-the-job training opportunities were not appropriately provided for the business educators and this had negative effect on their job performances. 
One of the findings of this present study discovered that in-service training opportunities in the various aspects of induction training, were not appropriately provided for the business educators. Only very few aspects of the induction training programmes opportunities were appropriately provided for business educators and they included that group discussions was organized for newly employed business educators together with other old staff to build their confidence about their job. A formal introduction about the school's philosophy, ethos, values, policy and culture was done so that educators are aware of the behaviours expected of them in performing their task for goal accomplishment. Other aspects of induction training were not appropriately provided for the business educators and they included aspects of organizing specific orientation to newly recruited business educators for them to understand the description of the job including the specification of their responsibility.

Physical tours around the school premises organized for newly employed business educators to get them accustomed to the workplace, and short seminar organized for newly employed business educators to get them acquainted with their subject area. A handbook/pamphlet was not appropriately delivered to business educators after recruitment in order to enable them to understand, likewise have knowledge about the school goals and objectives. All the above could have affected business educators' job performances which has negative consequences on effectively achieving the goals and objectives of business education in the secondary schools. This finding concurs with the findings of other scholars such as Ezugoh (2017) who found that in-service training programmes such as induction and orientation training, on-the-job training like mentoring, professional courses in adult education, free educational scholarship, long and short training courses abroad and computer-based training were not appropriately provided for educators for in order to improve their performances for facilitating learning in literacy centres.

Ofojebe and Chukwuma (2015) also confirmed that the utilization of continuous professional development - CPD for academic staff effectiveness in the higher education sector in contemporary Nigeria revealed the need for constant in-service and on-the-job training programmes to be organized for staff for their effectiveness and efficiency. These programmes were not effectively utilized by academic staff in higher education sector. On the contrary, Krueger and Rouse in a study cited in (Ezugoh, 2017) found that employees that attended in-service training, became more invested, committed and better working employees. These employees were shown to seek more job upgrades, receive more performance awards, and have better job attendance than those that did not attend training.

It was found in the findings of this study that in-service training opportunities in the various aspects of on-the-job training, were not appropriately provided for the business educators. Only very few aspects of the on-the-job training programmes opportunities were appropriately provided for business educators and they included that opportunities are created for business educators' job rotation in order to gain better insight of the school's organization for increased job performances. The business educators enjoyed transfer from one school to another in order to uncover their capacities likewise potentials to make positive impact on the job. They consulted with their senior colleagues or supervisors for guidance only when they face difficult task so that they are able to know how to perform the task and to what standard. All these programmes were not appropriate to determine the educators' effective job performances in the secondary schools in Delta State.

Other aspects of on-the-job training were not appropriately provided for the business educators and they included aspects of allowing the inexperienced business educators to be constantly coached by the older ones in order to lessen their chances of making mistakes on the job. Mentoring through observation of experts which served as means of improving business educators' high performances, were not appropriately provided. Computer-based training was not always provided for business educators in order to equip them with the necessary information to function actively in teaching and learning process as it relates to modern practices in business education. Opportunities for promotional training was not provided for business educator during promotions and workshops and seminars were not are constantly organized in the school for business educators to improve their competences for good performances in their profession.

This finding really differs from some of the studies like that of Walsh and Taylor (2007) whose finding has shown that in-service professional training activities are correlated with productivity and retention. The use of formal training programmes is associated with significantly higher productivity growth. Samupwa (2008) confirmed that there were positive effect of teacher training on the administrative work and teacher's behaviour in the classroom. 
Result showed significant changes in behaviour of the teachers in classroom and on the administrative work. From the finding of the study, business educators need to be supported through effective on-the-job training opportunities in order to boost their performances in the secondary schools in Delta State.

It was further discovered through the findings of the present study that in-service training opportunities in the various aspects of off-the-job training, were not appropriately provided for the business educators. Only very few aspects of the off-the-job training programmes opportunities were appropriately provided for business educators and they included that the business educators were allowed to engage in university higher degree education programmes like Masers and doctorate degrees in order to boost their careers in business education. Business educators with lower teaching qualification than the bachelors' degree like NCE and OND were allowed to upgrade their knowledge for better performance on the job by participation in off-the-job training programmes.

They engaged in open and distance learning (ODL) programmes in order to update and upgrade their knowledge in business education. However, many aspects of on-the-job training were not appropriately provided for the business educators and they included that the business educators were not appropriately encouraged to constantly attend their professional conferences outside the work environment as a way of building knowledge, understanding and competencies for overcoming future challenges. Free educational scholarships were not appropriately provided as means of improving the level of competences and upgrading the skills of business educators. Business educators were not sponsored on long training courses abroad during long vacations in business education as a way of developing of skills in business education, likewise, few weeks of short training courses abroad are always available for business educators.

Business educators were not appropriately sponsored to attend long training courses within Nigeria in order to improve their work effectiveness for higher productivity, likewise, short training courses within Nigeria were not appropriately provided for business educators to boost their skills on the job.

Also, the business educators did not receive apprenticeship training from other organizations such as small/medium scale industries (SMEs) and firms in order to boost their potentials for better practices in business education. All these affected and slowed down their job performances in the secondary schools. This finding is against the finding of Seyed, Hashemi and Ali (2014) which conducted a study and investigated ways of improving the effectiveness of the mechanisms in-service courses for Lamerd teacher's job performance in the fundamental transformation plan in the 2013-2014 years. The results showed that the growth and performance of in-service courses for teachers was effective, this owing to the continuous training they had. Ezugoh (2017) found that in-service training programmes such as on-the-job training and off-the-job training programmes like mentoring, professional courses in adult education, free educational scholarship, long and short training courses abroad and computer-based training were not appropriately provided for educators for in order to improve their performances for facilitating learning in literacy centres. Failure to recognize the importance of business educators' in-service training means that quality education will be difficult to enhance in business education. Opportunities should be created for business educators' in-service training for improvement in their job performances in secondary schools in Delta State.

\section{Conclusion}

Opportunities created for business educators' in-service training will definitely improve their work performances in business education. But the findings of the study revealed that in-services training opportunities in the various aspects of induction training, on-the-job and off-the-job training opportunities were not appropriately provided for the business educators and this affected their job performances. The in-service training programmes opportunities were not appropriate to guarantee business educators effectiveness on their job performances which could have had negative consequences on students' academic performances and interest in studying of business education in the secondary schools. This situation calls for priority attention in other to promote business educators job performances through appropriate in-services training programmes in Delta State. Based on the findings of this present study, recommendations were proffered below. 


\section{Recommendations}

1. Principals should ensure that newly employed business educators/teachers always undergo appropriate induction training programmes in order to boost their job performances. This includes that induction training programmes like specific orientation, physical tour around the school premises, short seminars and the school's handbook/pamphlet which describes the general philosophy, goals and objectives of the schools should highly be encouraged in the school for increased performances.

2. On-the-job training opportunities should be highly provided for business educators by their principals including the State Government and the Delta State Post Primary Education Board (PPEB). Offers should be opened appropriately for business educators' on-the-job training in the areas of coaching, mentoring, guidance, promotional training and organizing constant workshops and seminars in the school in order to improve their job performances.

3. Delta State Government in conjunction with the PPEB should support business educators' off-the-job training opportunities through appropriate legislation, policy and financial sponsorship.

Adequate finances should be provided to create opportunities for business educators in the areas of attending their professional conferences, providing free scholarship in business education, apprenticeship training from SMEs industries and firms and by sponsoring long and short training courses for business educators in Nigeria and outside the country internationally for educators improved job performances in the teaching profession.

\section{References}

Agu, N. N. (2014). The professional practices of the Nigerian teacher and contemporary issues for quality assurance. Journal of Education, the Teacher and Professional Practices (JOETEPP), l (1), 10-31.

Ezugoh, T.C. (2017). Motivational strategies provided for educators for facilitating learning in adult literacy centres in Delta State (Unpublished master degree thesis). Faculty of Education, Nnamdi Azikiwe University, Awka.

Federal Republic of Nigeria (FRN, 2013). National policy on education. Lagos: NERDC.

Kaur, K. (2012). Staff development programme. Retrieved from https://www.slideshare.net/monekhangura/staffdevelopment-programme

Manduku, J., Edward, B. \& Cheruiyot, A. (2017). In-service teacher training programmes: Implications on teacher effectiveness in secondary schools in Kenya. European Journal of Education Studies, 3 (7), 189-202.

Munir, S. \& Khatoon, T. (2015). Job satisfaction scale. International Journal of Multidisciplinary Research and Development, 2 (8), 454-457.

Nworgu, B.G. (2015). Educational research. Basic issues and methodology, third edition. Nsukka: University Trust Publishers.

Ofojebe, W.N. \& Chukwuma, E.T.C. (2015). Utilization of continuous professional development for academic staff effectiveness in the higher education sector in contemporary Nigeria. Journal of Emerging Trends in Educational Research and Policy Studies (JETERAPS), 6 (4), 306-314.

Onajite, G.O. \& Oyerinde, D.O. (2015). Promoting institutional collaborations for capacity improvement of business educators in tertiary institutions in Delta State of Nigeria. Journal of Education and Practice, 8 (14), 79-81.

Samupwa, M. (2008).Teacher training and work behavior. International Journal of Human Resources, 65, 88-98.

Seyed, A., Hashemi, E. A. \& Ali, P. (2014). Ways to enhance the effectiveness of the mechanisms of in-service courses on Lamerd job performance of teachers in fundamental transformation plan. Kuwait Chapter of Arabian Journal of Business and Management Review, 4 (1) 333 - 343.

Udeozor, R.K. (2004). Educational administration: Perspectives and practical implications. Nimo: Rex Charles and Patrick Limited.

Valdez, G. (2006). Critical issue: Technology. A Catalyst for Teaching and Leaning in the Classroom. Retrieved from http://www.ncrel.org/sdrs/areas/issues/methods/technlgy/te600.htm

Walsh, K. \& Taylor, M. (2007). Developing in-house careers and retaining management talent. Cornell Hotel and Restaurant Administration Quarterly, 48 (2), 16382.

Zamumuzi, P. C. (2004). How effective is in-service training for teachers in rural school contexts? (M.PHIL. Thesis). University of Pretoria, South Africa. 